\title{
GM.CD40L Cell Vaccine
}

National Cancer Institute

\section{Source}

National Cancer Institute. GM.CD40L Cell Vaccine. NCI Thesaurus. Code C48391.

A cell-based vaccine composed of irradiated tumor cells transduced with granulocytemacrophage colony-stimulating factor (GM-CSF) and CD40-lig and (CD40L) genes. Upon administration, this vaccine may stimulate an anti-tumoral dendritic cell-mediated host immune response. ( $\mathrm{NCl05)}$ 